The published version of this appears in: Journal of Germanic Linguistics 27.1 (2015)

\title{
Ceci n'est pas une tussentaal. Evoking standard and vernacular language through mixed Dutch in Flemish telecinematic discourse
}

Jürgen Jaspers, Université Libre de Bruxelles (ULB)

Sarah Van Hoof, University of Oslo

This paper argues that the use of mixed Dutch, the speech style that Flemish linguists have come to name tussentaal (literally 'interlanguage') and which is made up of dialect and standard features, can index meanings conventionally associated with dialect and Standard Dutch, depending on the linguistic ecology in which it occurs. Consequently, and in contrast with current explanations that attribute context-independent social meaning to tussentaal, we argue that its meaning needs to be identified relative to the unfolding interaction in particular contexts of use. Using a corpus of Flemish telecinematic discourse, we suggest that this finding calls for a renewed appreciation of tussentaal in relation to burgeoning hypotheses of destandardization.

\section{Introduction.}

It is an understatement to say that Flanders, the Dutch-speaking northern half of Belgium, has in the last two decades taken an interest in a colloquial and mixed variety of Belgian Dutch. This variety is commonly known as tussentaal, literally 'interlanguage' or 'in between language' because it cannot be considered either dialect or Standard Dutch but is a mix of the two. To be sure, tussentaal has frequently

- The first author was supported by a grant from The Netherlands Institute for Advanced Study in the Humanities and Social Sciences (NIAS). The second author was supported by the Research Council of Norway through its Excellence funding scheme, project number 223265. The authors wish to thank two anonymous reviewers for their very useful feedback and suggestions. 
managed to set this part of the world on discursive fire, its occurrence and spread sparking fierce criticism from linguists, educators, journalists, policy makers of all stripes, literary authors, as well as the general public. Secondary school books teach pupils to disapprove of this "grubby, rotten Dutch." ${ }^{1}$ Eminent linguists and literary authors categorize it as "lazy Flemish," "hamburger language," "soap Flemish," "crooked language," or "jabber- Flemish," ${ }^{2}$ and political party brochures and official linguistic policy documents describe tussentaal as a dangerous force that needs to be cracked down upon to safeguard equal opportunities in education and efficient nationwide communication (for analyses and examples, see Jaspers 2001, Jaspers \& Brisard 2006, De Caluwe 2009, Grondelaers \& van Hout 2011, Absillis et al. 2012, De Schryver 2012, Jaspers \& Van Hoof 2013, Van Hoof, in press). This hostile climate notwithstanding, most Flemish linguists are convinced that the "standard variety of Belgian Dutch ... is in any case losing ground" to tussentaal (Grondelaers \& van Hout 2011:221), and many of them are arguing that the dissemination of this colloquial speech style may itself come to represent an autonomous, bottom-up linguistic standardization process (De Caluwe 2002:58, Janssens \& Marynissen 2005:196, Vandekerckhove 2005, Grondelaers \& van Hout 2011:221) or may develop into a regular nation-wide colloquial variety, or UMGANGSSPRACHE (Willemyns 2005:30).

Paradoxically, however, in light of the considerable popular and academic attention it has received, there is ample uncertainty over what tussentaal actually is or what structural features it consists of: "Although tussentaal is immediately recognizable to Belgian listeners, it cannot easily be characterized in terms of necessary and sufficient features" (Grondelaers \& van Hout 2011:222; compare Willemyns 2003:362). In relation to how this way of speaking has come to be named tussentaal 'in between language', some linguists have assumed a tri-polar model that posits tussentaal as a separate, intermediate variety

\footnotetext{
${ }^{1}$ See De Schryver et al. 2012:145 for this and other examples.

2 Taeldeman in Notte \& Scheirlinck 2007, Taeldeman 1992:37, Geeraerts 1998, Hertmans 2012, Barnard 1999, respectively.
} 
in between the "higher" standard variety and the "lower" basilectal dialects (compare Geeraerts et al. 1999, Geeraerts \& De Sutter 2003, Taeldeman 2008, Cajot 2012).

In this vein, a number of authors have produced descriptions of tussentaal that propose a limited set of usually nonlexical core features (for example, Goossens 2000, Plevoets et al. 2007, Rys \& Taeldeman 2007, Taeldeman 2008), that are argued to "acquir[e] a stable position in this intermediary variety" (Taeldeman 2008:26). Others have pointed out that the proposed lists of defining features vary greatly (De Schryver 2012), and that there are few reasons to assume that tussentaal, or any other alternative term for it, necessarily rings any bells with nonlinguists or is recognized by them as a distinct variety they deliberately choose to speak or switch to in interaction (Slembrouck \& Van Herreweghe 2004: 864, De Caluwe 2009:16, Lybaert 2011).

In addition, some empirical analyses indicate that speakers do not switch neatly from tussentaal to Standard Dutch or dialect, but often produce unpredictable, eclectic, "messy" code mixes that range from being more dialectal to fairly standard, complicating the unambiguous classification of utterances as dialect, tussentaal, or Standard Dutch (compare Vandekerckhove \& Nobels 2010). ${ }^{3}$ As a result, some authors have argued that tussentaal needs to be seen as part of a DIAGLOSSIC, continuum without any discrete intermediate strata (Plevoets 2008, De Caluwe \& Van Renterghem 2011, Ghyselen 2011, Grondelaers \& van Hout 2011; also see Auer 2005) or as "een matrix van taalgebruik, waarvan de dimensies welbekend zijn, maar de gerealiseerde taalpraktijk veel minder voorspelbaar" (Slembrouck \& Van Herreweghe 2004:862- 863; see also Jaspers 2001, Vandekerckhove \& Nobels 2010). ${ }^{4}$

Furthermore, several authors have formulated hypotheses for tussentaal's success, often explaining the occurrence of this way of

\footnotetext{
${ }^{3}$ Also see Jaspers 2011:496 and Rampton 2006 for similar observations of how adolescents move between "more dialectal" and "more standard" speech, hardly ever producing idiomatic examples of either.

${ }^{4}$ a matrix of language use with familiar dimensions but much less predictable outcomes (translation throughout the paper is ours).
} 
speaking as oppositional to Standard Dutch. Thus, Van Gijsel et al. (2008:220) propose that, for adolescents especially, tussentaal "has young, even somewhat rebellious, connotations, as opposed to the 'conformist' norm of the standard language," or that many Flemings consider tussentaal more "authentic" or "natural" as opposed to an external, namely, standard norm. This is seen to offer a functional motivation for its use in a society where Flemings increasingly view Standard Dutch as an "artificial" or inauthentic variety imposed on them from above.

Plevoets $(2009,2012)$ postulates that tussentaal is a badge of the Flemish elite who have maximally profited from the region's socioeconomic welfare, which has increased considerably after the Second World War. Having reached the top positions in Flemish society, this elite can now resist the pressure of acquiring prestigious linguistic forms, or display indifference to them. In Bourdieu's (1991) words, they can afford to be "hypocorrect," that is, conspicuously relaxed or intentionally less than correct-similar to the practice Bourdieu observed among the French bourgeois seeking to distinguish themselves from the petit-bourgeois, who, in their efforts to imitate them, were becoming hyper-correct, tense, and linguistically anxious (1991:63).

Grondelaers \& van Hout (2011), in turn, suggest that the triumph of tussentaal may have to be attributed to, among other things, i) an increased Flemish self-consciousness in the wake of the region's augmented political and economic power within the Belgian state, which dimmed erstwhile language-integrationist ambitions and raised ambitions for a separate Flemish standard (also see Goossens 2000), ii) an increased democratization of social life that facilitates vernacular language use in public, and iii) an anti-authoritarian, post-1968 grudge against what is, essentially, a foreign and repressively installed linguistic standard. In addition, Grondelaers \& van Hout (2011) put forward that the "highest" spoken variety in Flemish Belgium is so-called VRT Dutch, the language spoken by newscasters and most presenters on the Flemish public broadcaster VRT, but that this variety is hardly ever spoken outside of broadcasting contexts (see also De Caluwe 2009). ${ }^{5}$

\footnotetext{
${ }^{5}$ VRT is short for Vlaamse Radio en Televisieomroeporganisatie 'Flemish Radio
} 
Grondelaers et al. (2011) in this time frame conducted an evaluation experiment showing that speakers of Belgian Dutch consider none of the other (regionally colored) varieties currently in use as "the best language." They concluded that whereas tussentaal may be on its way to becoming the new standard of Dutch in Flanders, "Belgian Dutch is currently a standardless variety" (Grondelaers et al. 2011:200), and consequently "the Belgian standard situation clearly represents a case of Fairclough's (1992) destandardization" (2011:218; see also Willemyns 2007, van der Horst 2008). ${ }^{6}$ In a more recent speaker evaluation experiment reported in Grondelaers \& Speelman 2013, lexical tussentaal features scored high on "dynamism." Based on this finding, the authors argued "that by using typically Flemish lexemes, speakers project a trendy, assertive image" (2013:184), and hypothesized that these prestige values could be the driving force behind the emergent standardization of tussentaal.

In this paper, we would like to argue that even though tussentaal may, in some contexts, index anti-authoritarian resentment, rebelliousness, assertiveness, or trendiness, these meanings cannot be taken to hold across the board. Drawing on interactional data from a telecinematic corpus (Van Hoof 2013), we demonstrate that what from the structural point of view can be called mixed Dutch (conventionally, tussentaal) can help index a very diverse range of meanings, including those that are traditionally associated with Standard Dutch or dialect, depending on the local linguistic ecology (Haugen 1972). This finding confounds any suggestion that the use of tussentaal essentially signals rebellion, authenticity, conspicuous relaxation, nonformality, or selfconsciousness, and necessitates an interactional analysis of how linguistic features are interpreted by interactants in specific situations.

and Television Broadcasting Organization'.

${ }^{6}$ Note, though, that Fairclough does not use the term destandardization but discusses a broader process of democratization in the public sphere, which, among other things, involves increased access for individual speakers to a range of formerly exclusive contexts. Increased nonstandard language use can be seen as a consequence of this broader process. 
It also complicates analyses that automatically or necessarily associate the use of tussentaal with speakers' negative attitudes toward dialects and/or Standard Dutch (compare Taeldeman 2008:29 and others), and with any intention to produce a mixed type of Dutch.

In sum, and following Coupland (2010:60), we demonstrate that in principle, "we cannot identify what a standard or non-standard variant is, independently of social judgments that are made about its use or users," and this implies that what looks like tussentaal in etic terms may mean something quite different when examined from an emic perspective. Regardless of its stabilizing or unpredictable nature, we argue therefore that the occurrence of tussentaal cannot simply be taken as an unambiguous sign of destandardization processes.

\section{Context: Tussentaal in Flemish Public Discourse.}

The corpus we draw on is part of a larger study that investigates the evolution of language use in Flemish telecinematic comedy and drama between the early 1980s and the late 2000s (Van Hoof, in press). TV series and films are frequently targeted in the criticism of tussentaal, because they are seen as uncritically promoting it and as having drifted away from the earlier days in which actors still used "proper" Standard Dutch (for an overview of these criticisms, see Van Hoof, in press:12ff). Even if these assertions may be difficult to prove empirically, they are typical for the context in which these TV series and films are produced, and it is worth briefly sketching it before going into an analysis of the data.

One crucially distinctive characteristic of linguistic standardization in Flanders is that stakeholders in the 19th century decided not to develop a Standard Flemish but to adopt the linguistic standard in use in the Netherlands, "Standard Dutch." In brief, three reasons were behind this decision. First, an endogenous Standard Flemish was not trusted to hold its own next to French in Belgium. Second, Flemish was considered to be too corrupted by French and thus all too symptomatic of French domination. Third, a choice for Standard Dutch would allow Flemings to "set history right" in that it would imply linguistically recreating a unity that the Eighty Years' War had destroyed through splitting the Low Countries in two (Deprez 1999, Willemyns 1996, 2013). Consequently, Flemings needed to be made familiar with an imported linguistic 
standard, and this gave rise to a blooming tradition of linguistic purification. From the 1950s onwards, this project turned into a largescale, fiercely propagandistic, and extensively mediatized linguistic standardization campaign that has successfully "enregistered" (Agha 2007) Standard Dutch and its linguistic opposites in all corners of Flemish society-a process we have labeled "hyperstandardization" (Van Hoof \& Jaspers 2012, Jaspers \& Van Hoof 2013).

The Flemish public broadcaster VRT was a key player in this enregisterment process. Its directors considered language a cornerstone of their at the time explicitly civilizational broadcasting mission, and engaged linguists to ensure that all microphone employees spoke an impeccable Standard Dutch. Moreover, for decades the VRT offered prime time slots to Flanders' linguistic purifiers (Vandenbussche 2010). The most well-known example is the instructive television program Hier spreekt men Nederlands 'Here one speaks Dutch', broadcast three days a week in the 1960s and 1970s. ${ }^{7}$ It focused on speech purification (weeding out dialectal features in civilized speech) and speech typification, linking Standard Dutch and dialect to a set of social personae and stances (Agha 2003:237). In particular, Standard Dutch was propagated as the hallmark of a civilized, gentleman-like, stylish, modern, polite speaker, while Flemish dialects were associated with the opposite of these qualities (see, for example, Florquin 1965). To this date, the hope has always been that Standard Dutch would not just remain a variety for special, formal occasions but would eventually anchor itself firmly in Flemings' daily lives as an "informal Standard Dutch" (see, for example, Hendrickx 1998).

These standardization efforts notwithstanding, the VRT has recently found itself the target of more and more complaints with regard to the language of its broadcasts. Journalists, teachers, writers, and linguists often protest that language on television is rapidly deteriorating. Especially the "lighter" genres, such as talk shows, comedy shows, or soap operas, regularly find themselves in the line of fire. During the question period at the Flemish parliamentary meeting on November 29, 2012, one MP bemoaned that "up until forty years ago VRT series in

\footnotetext{
${ }^{7}$ The name of the program implies that one does not and must not speak
} anything less than Standard Dutch, such as, for example, Flemish or French. 
tussentaal would have been absolutely impossible" (Vlaams Parlement 2012), and subsequently complained to the Minister of Culture that Flemish government did far too little to oppose the advance of so much linguistic indolence. ${ }^{8}$ The highly popular nationalist and conservative politician Bart De Wever, who is himself often accused of speaking tussentaal, alluded to deteriorating linguistic standards as a proxy for falling norms in society: ${ }^{9}$

Nivelleren naar boven werd ingeruild voor nivelleren naar beneden, met een enthousiasme alsof diarree de ideale remedie zou zijn voor constipatie. De gevolgen zie je het best aan ons taalgebruik. Het streven naar het doorsijpelen van algemeen Nederlands werd zo goed als opgegeven. Zelfs de openbare omroep vindt het vandaag normaal om populaire series te maken waarin de acteurs een soort tussentaal spreken. ... Het resultaat is een veralgemening van een soort randstedelijk Antwerps, gelardeerd met exotische klanken en uitdrukkingen uit andere provincies. ${ }^{10}$ (De Wever 2007)

Leveling up has been turned in for leveling down, with an enthusiasm as if diarrhea were the ideal remedy for constipation. Our language use best shows what the consequences are. Attempts to disseminate Standard Dutch in society have been all but relinquished. Even the public broadcaster today considers it normal to make popular series where actors speak some kind of tussentaal. ... The result is a

\footnotetext{
${ }^{8}$ Besides electing a national federal parliament, Belgian citizens also elect various regional parliaments, depending on their regional location, such as the parliament of the Flemish community.

${ }^{9}$ See Camps 2011

${ }^{10}$ The Antwerp regiolect is often felt to predominate in vernacular language use on television, and tussentaal use is often perceived to be especially colored by features of which the origins can be traced to the central dialect area (consisting of the provinces of Antwerp and Flemish Brabant, as opposed to the peripheral (West-Flemish and Limburg) dialect regions.
} 
generalization of some sort of suburban Antwerp dialect, larded with exotic sounds and expressions from other provinces.

Journalist and historian Marc Reynebeau summarized the whole issue as follows:

[E]r is amper nog AN te horen, niet op school en niet in de massamedia. Behalve in journaals en andere ernstige programma's hanteert zelfs de openbare omroep steeds minder het AN, zeker niet in talkshows of fictieprogramma's. Mensen moeten zich in fictie kunnen herkennen, heet het dan, en het klopt dat dat niet kon met het bombastische theater-ABN van vroeger. (Reynebeau 2006)

[W]e hardly hear Standard Dutch anymore, not at school and not in the mass media. Except for the news and other serious programs, even the public broadcaster is using Standard Dutch less and less, and certainly not in talk shows or TV fiction. People are supposed to recognize themselves in fiction, so it goes, and it is true that that was impossible with the bombastic theatre Standard Dutch of before.

Quotes such as these are representative of the widespread opinion that before, the language of comedy and drama series on the public broadcaster was Standard (even at times somewhat "bombastic") Dutch, whereas contemporary series (and films) have all fallen prey to tussentaal. The turning point is usually situated around 1989, the year when the first commercial TV station VTM started broadcasting in Flanders. Janssens \& Marynissen (2005:198) sum up the consequences of the end of the VRT's broadcasting monopoly as follows: ${ }^{11}$

Om hoge kijkcijfers te halen en adverteerders te kunnen aantrekken, programmeerde VTM niet alleen recente speelfilms maar ook veel populaire soaps, (vragen)spelletjes en andere ontspanningsprogramma's. De meeste acteurs in deze soaps en

\footnotetext{
${ }^{11}$ See also Taeldeman 2008:30 and Van de Velde 1996:267-268.
} 
vele deelnemers aan de spelletjes en amusementsprogramma's spraken de taalvariëteit die in Vlaanderen gebruikelijk was: tussentaal. ... En ook op de [V]RT deed deze variëteit geleidelijk haar intrede in soaps en dergelijke, en op de radio in reclameboodschappen. (emphasis is ours-JJ\&SVH)

In order to attain high viewer ratings and advertisers, VTM not only scheduled recent films but also many popular soaps, quiz games, and other entertainment. Most actors in these soaps and the many participants in these quizzes and entertainment shows spoke the common linguistic variety in Flanders: tussentaal. ... Gradually, this variety also made its entry on the $V R T$ in soaps and other programs, and in radio commercials.

It is no coincidence in this context that "soap Flemish" (Geeraerts 1998) has become a popular label for tussentaal. The term refers to the genre of the soap opera, introduced in Flanders by the commercial broadcaster and later also adopted by the VRT. This type of low-cost, quickly produced TV fiction is often frowned upon as low-quality television, a connotation that is easily extended to the language it uses.

\section{Tussentaal in Flemish Telecinematic Discourse.}

That the above analyses require some revision is demonstrated by Van Hoof \& Vandekerckhove's (2013) quantitative analysis of language use in several TV fiction series broadcast by the VRT around 1980 (that is, before the arrival of commercial television) and in the late $2000 \mathrm{~s} .{ }^{12}$ In focusing on TV fiction series, Van Hoof \& Vandekerckhove align themselves with the burgeoning interest in so-called telecinematic discourse (see, for example, Queen 2004, Richardson 2010, Piazza et al. 2011, Androutsopoulos 2012). This interest is driven by the realization that as all language use is essentially constructed and performed, excluding the

\footnotetext{
${ }^{12}$ The corpus contained one episode of each series the VRT broadcast between 1977 and 1985 (13 in total) and one episode of each series broadcast between 2008 and 2009 ( 8 in total).
} 
language of fictional characters from sociolinguistic analysis as "inauthentic" or "unreal" means overlooking an important part of daily language use. It would also mean disregarding that authenticity or "realness" is a product of social interaction, and is "always achieved rather than given in social life, although this achievement is often rendered invisible" (Bucholtz 2003:407-408).

Under this approach, fictional interaction can be investigated as social interaction in its own right, with no presumption that the social meanings of linguistic features in the nonfictional world would simply be reproduced or can be taken for granted in the fictional world. Indeed, research in this tradition often works from the assumption that linguistic resources and their social meanings are RECONTEXTUALIZED in telecinematic discourse, depending on the dramatic conditions on hand, the relations between characters, and the development of the narrative (compare Coupland 2007). In other words, linguistic features contribute to the construction of DIEGETIC worlds, that is, the story worlds of films or TV series (Elsaesser \& Hagener 2010:5), and are as such to be interpreted within these diegetic ecologies.

Telecinematic discourse has proven to be particularly apt for exploring how linguistic variation is associated with certain social stances, activities and identities, or is "enregistered" (Agha 2003), and for investigating how such metapragmatic work reproduces, contests or temporarily inflects the larger-scale, real-world metadiscursive regimes in which the fictional product is embedded. While most analyses in this tradition are of a qualitative nature, Van Hoof \& Vandekerckhove (2013) produced a quantitative analysis in order to obtain a broad appreciation of linguistic evolutions in the abovementioned corpus, and to test the popular claim that language use in TV fiction has shifted from predominantly Standard Dutch to mostly tussentaal.

To this end, Van Hoof and Vandekerckhove selected seven morphosyntactic variables, each with one or several standard variants and one or several nonstandard variants considered in the literature as typical markers of tussentaal (see Goossens 2000, Plevoets et al. 2007, Rys \& Taeldeman 2007, Taeldeman 2008), and compared their occurrence in the series aired around 1980 and those broadcast in the late 2000s. The seven variables they selected are listed in table 1 (below).

The nonstandard variants, however, cannot be taken as exclusive 
markers of tussentaal. Without going into too much detail, typical for the speech style that linguists term tussentaal is the frequent use of socalled tertiary, that is, general, or geographically widespread dialect features (Taeldeman 2006, Rys \& Taeldeman 2007), such as the nonstandard variants listed above, and rather limited use of secondary and primary dialect features, which are more strongly regionally or locally colored and can be considered markers of (more) fully-fledged dialect use. Thus, the use of a feature such as double negation in itself may mark both tussentaal and dialect use. Van Hoof and Vandekerckhove (2013) therefore also included in their analysis two dialect markers that are typically not transferred to tussentaal (Rys \& Taeldeman 2007:5) and thus allowed to filter out dialect use. Each marker had a standard variant and several dialect variants. These markers are displayed in table 2.

Van Hoof \& Vandekerckhove (2013), using mixed-effects logistic regression, assessed the effect of period (1980 versus present) on language variety (standard versus nonstandard), including estimates of the speakers' dialect use as a covariate. Apart from the fixed effects of period and dialect use, the model contained random effects of series, speaker, and marker. Van Hoof \& Vandekerckhove found that period had a significant positive effect on language variety, and that exclusion of the covariate dialect use severely weakened the effect of period, due to the higher occurrence of dialect in TV fiction around 1980.

\begin{tabular}{|l|l|l|}
\hline \multicolumn{1}{|c|}{ Variables } & \multicolumn{1}{c|}{ Standard variant } & \multicolumn{1}{c|}{ Tussentaal variant } \\
\hline $\begin{array}{l}\text { 1. Realization } \\
\text { of } \\
\text { end-/t/ }\end{array}$ & $\begin{array}{l}\text { [t] } \\
\text { dat probleem } \\
\text { waarom niet? } \\
\text { wat is er } \\
\text { gebeurd? }\end{array}$ & $\begin{array}{l}\text { [d] or } \varnothing \\
\text { da probleem 'that problem' } \\
\text { waarom nie? 'why not' } \\
\text { wad is er gebeurd? 'what } \\
\text { happened' }\end{array}$ \\
\hline $\begin{array}{l}\text { 2. Realization } \\
\text { of onset-/h/ }\end{array}$ & $\begin{array}{l}\text { [h] } \\
\text { mijn hoofd }\end{array}$ & $\begin{array}{l}\varnothing \\
\text { mijn 'oofd 'my head' }\end{array}$ \\
\hline $\begin{array}{l}\text { 3. Adnominal } \\
\text { flexion with } \\
\text { masculine } \\
\text { singular nouns }\end{array}$ & $\begin{array}{l}\varnothing \text { or }-\mathrm{e} \\
\text { de hond } \\
\text { een grote stoel } \\
\text { mijn stoel }\end{array}$ & $\begin{array}{l}\text {-e or -en } \\
\text { den 'ond 'the dog' } \\
\text { ne grote stoel 'a large chair' } \\
\text { mijne stoel 'my chair' }\end{array}$ \\
\hline
\end{tabular}




\begin{tabular}{|l|l|l|}
\hline & $\begin{array}{l}\text { onze hond } \\
\text { die dikke vinger }\end{array}$ & $\begin{array}{l}\text { onzen 'ond 'our dog' } \\
\text { dieën dikke vinger 'that fat } \\
\text { finger' }\end{array}$ \\
\hline $\begin{array}{l}\text { 4. Realization } \\
\text { of diminutive }\end{array}$ & $\begin{array}{l}\text {-je } \\
\text { appeltje }\end{array}$ & $\begin{array}{l}\text {-ke } \\
\text { appelke 'a little apple' }\end{array}$ \\
\hline $\begin{array}{l}\text { 5. Subject } \\
\text { forms of } \\
\text { second person } \\
\text { singular } \\
\text { pronoun }\end{array}$ & $\begin{array}{l}\text { je, jij, u } \\
\text { je/u weet } \\
\text { jij/u moet } \\
\text { wist je/jij/u dat? } \\
\text { heb je/heb } \\
\text { jij/hebt } \text { u dat } \\
\text { gezien? }\end{array}$ & $\begin{array}{l}\text { ge, gij, -de (gij), -te (gij) } \\
\text { ge weet 'you know' } \\
\text { gij moet 'you have to' } \\
\text { wiste da?/wiste gij da? 'did } \\
\text { you know that?' } \\
\text { 'ebde/ebde gij da gezien? } \\
\text { 'have you seen that?' }\end{array}$ \\
\hline $\begin{array}{l}\text { 6. Realization } \\
\text { of subordinate } \\
\text { word } \\
\text { preceding } \\
\text { dependent } \\
\text { clause }\end{array}$ & $\begin{array}{l}\text { } \\
\text { Hij vraagt of dat } \\
\text { kan. } \\
\text { Ik weet wie er } \\
\text { komt. }\end{array}$ & $\begin{array}{l}\text { dat } \\
\text { Hij vraagt of dat da kan. 'He } \\
\text { asks if that is possible' } \\
\text { Ik weet wie dat er komt. 'I } \\
\text { know who's coming' }\end{array}$ \\
\hline 7. Negation & $\begin{array}{l}\text { Single negation } \\
\text { Ik heb daar } \\
\text { niemand gezien. } \\
\text { Ik zal niet lang } \\
\text { meer leven. }\end{array}$ & $\begin{array}{l}\text { Double negation } \\
\text { Ik 'eb daar niemand nie } \\
\text { gezien. 'I haven't seen anyone } \\
\text { there' } \\
\text { lk zal nie lang nie meer leven. } \\
\text { 'I won't be living for long' }\end{array}$ \\
\hline
\end{tabular}

Table 1. Markers of tussentaal. ${ }^{13}$

\footnotetext{
${ }^{13}$ For more detailed discussions of these features, see Rys \& Taeldeman 2007 and Taeldeman 2008. The first two markers are mostly considered to be features of tussentaal, but they also occur in more formal registers (compare Grondelaers \& Speelman 2013:183). We treat them here, in line with other research, as markers of tussentaal, but this in itself precisely illustrates that even individual features cannot be taken to index the same meaning overall, in each instance of use (see section 4).
} 


\begin{tabular}{|l|l|l|}
\hline \multicolumn{1}{|c|}{ Variables } & Standard variant & \multicolumn{1}{c|}{ Dialect variant } \\
\hline $\begin{array}{l}\text { 1. Realization } \\
\text { of half-close /e:/ }\end{array}$ & $\begin{array}{l}\text { [e:] } \\
\text { Been }\end{array}$ & $\begin{array}{l}\text { [iə], [eə], [i:] } \\
\text { bieën, beeën, bien 'leg' }\end{array}$ \\
\hline $\begin{array}{l}\text { 2. Realization } \\
\text { of onset-/o:/ }\end{array}$ & $\begin{array}{l}\text { [o:] } \\
\text { boom }\end{array}$ & $\begin{array}{l}\text { [uગ], [oə], [yə], [u·] } \\
\text { boeëm, booëm, buuëm, } \\
\text { boem 'tree' }\end{array}$ \\
\hline
\end{tabular}

Table 2. Markers of dialect use.

Rather than evidencing a straightforward decrease in the use of Standard Dutch in favor of tussentaal, these findings indicate that nonstandard language use has been an integral part of Flemish TV fiction for at least 30 years. It would be thus difficult to associate the increase in the use of tussentaal with the arrival of commercial television in Flanders, since this type of language use was already used on television long before "changes in the Flemish media landscape" (Janssens \& Marynissen 2005:189) took effect.

That said, Van Hoof \& Vandekerckhove 2013 demonstrate that language use in TV series in the 1980s covered a much wider spectrum than it does today. Apart from tussentaal, Standard Dutch and dialect were also used regularly in early 1980 s fiction. Today, however, the use of tussentaal dominates the genre and offers its services to a much wider range of characters and situations than in the 1980s corpus, at the expense of Standard Dutch and dialect. In other words, language use in Flemish fiction series has evolved in two directions at the same time, namely, away from Standard Dutch and away from the Flemish dialects.

\section{An Interactional Approach.}

Van Hoof \& Vandekerckhove's (2013) analysis provides a general characterization of linguistic variation in Flemish TV series, and of its evolution in 30 years' time. It shows to what extent characters and series make use of linguistic features that are conventionally labeled as indicative of varieties such as Standard Dutch, dialect, or tussentaal. In covering the entire spectrum between Standard Dutch and dialect, language use in a fictional setting attests to the diaglossic nature of the 
linguistic situation in Flanders (even if contemporary series appear to cover a shorter continuum than the 1980 s series).

At the same time, the analysis also shows that certain linguistic features in effect do tend to conglomerate, which explains why tussentaal is often viewed as a distinct, bounded variety: Whereas eclectic mixes are, in principle, quite possible (for example, dialectal realizations of the dialect markers in table 2 could be combined with standard realizations of the tussentaal markers in table 1), such mixes are rarely produced by the characters in the corpora. The mixed, intermediate way of speaking that Flemish linguists have labeled tussentaal tends to come in fairly predictable guises (certain combinations are frequent, others fairly exceptional).

Nevertheless, although it can be applied to a large amount of data to provide a panoramic view, the quantitative analysis described above has a number of shortcomings. First, it uncovers structural tendencies, but it does not explain why the language of fiction has taken the form that it has over the last 30 years. An answer to that question has to be sought in the social meanings carried by linguistic forms in TV series of the 1980s and today. Incorporating more independent variables into the analysis may provide a starting point for identifying those meanings. Investigating the possible effect of the variable genre, for example, might reveal that comedy and drama favor different kinds of language use (presumably the nonstandard kind in the case of the former; compare Androutsopoulos 2012:146). Series aiming to be realistic would probably display patterns of social stratification, where characters with a higher socio-economic status score higher on the use of standard variants than lower class characters (compare Geeraerts 2001). Thus, the variable social class may also contribute to a more detailed quantitative analysis. But, and second, even the most fine-grained quantitative investigation of language use has the shortcoming of attributing an absolute-that is, context-independent-meaning to the variants earmarked as symptoms of tussentaal, dialect, or Standard Dutch. These variants are not allowed to jump ship, and are assumed to have the same meaning across all contexts under consideration.

In contrast, interactional approaches have over the years pointed out that the meaning of linguistic features-and of the sociolinguistic activities they help construct-is relative to the unfolding interaction in 
a specific context and can be subject to significant reinterpretation when features are transferred across contexts:

[T] he same semiotic acts or processes [can] mean very different things in different environments. Shifts across environments involv[e] shifts in function, the attribution of different meanings and values to the same semiotic action, object or process.

(Blommaert 2005:172).

Coupland (2010:62) likewise argues that

... judgement/attitudes research has always shown that the social meanings of linguistic varieties are complex and multidimensional ... [and that] contextual factors impinge crucially on which social meanings are attributed to varieties. ${ }^{14}$

In other words, the same verbal performances can be intended or interpreted differently, depending on how speakers are perceived (for example, as a conventional dialect or Standard Dutch speaker, as a learner of Dutch), on what relationship speakers have with one another (for example, hierarchical or sociable), on the particular social environment or regime of linguistic expectations they find themselves in (for example, at home or at school), and on how the performance is keyed (jocular or serious). Frequency counts, however, classify inauthentic, caricatured language use as similar to conventional, nonironic language use.

In sum, while it is clear that a quantitative approach has helped to reveal structural tendencies in our corpus that a qualitative analysis would be at pains to provide, such an approach necessarily abstracts away from the specific situations in which various features appear. Consequently, a quantitative approach often fails to determine how particular linguistic features are interpreted in particular situations of use, and ignores whether such features can actually be seen as true representatives of the varieties that the quantitative analysis has

${ }^{14}$ See also Slembrouck \& Van Herreweghe 2004, Jaspers \& Brisard 2006; Eckert 2012 on "bricolage". 
already decided that they are. As a result, there is a risk of reading meanings into the use of features that are not warranted by how they are recruited in dialogue by specific characters, and of overlooking how the insertion of these features speaks to the social environment or linguistic ecology (Haugen 1972, Mühlhäusler 1996) that the series and the characters (re)create.

These considerations do not invalidate the use of quantitative approaches per se. But on the basis of the literature reviewed above, any use of tussentaal signals a rebellious, authentic, conspicuously relaxed, nonformal, or self-conscious interactional stance. In the next section, we discuss the interactional account of two scenes analyzed at length in Van Hoof, in press. Given this account, we suggest that what many Flemish linguists would characterize, based on its structural properties, as an instance of tussentaal "contribute[s] to the construction of different identities, depending on how they are locally contextualized" (Coupland 2009:288), and flags a range of other meanings than what tussentaal has hitherto been allowed to index. If occurrences of tussentaal cannot be trusted to stand for its traditionally attributed meanings, tussentaal research in general (quantitative and qualitative) may have to reconsider some of its assumptions. ${ }^{15}$

\section{Tussentaal Functioning as Standard Dutch.}

Our first example comes from the recent film Groenten uit Balen 'Vegetables from Balen' (2011), a screen adaptation of Walter Van den Broeck's play of the same title. ${ }^{16}$ The movie depicts the strike that broke out in the Vieille Montagne zinc factory in Balen-Wezel (some 70 kilometers east of Antwerp, Belgium) in 1971. For this film, director Frank Van Mechelen cast mostly actors originating from the Campine area and asked them to speak in their native dialect, accounting for this choice as a way to achieve realism. According to Van Mechelen, the film

\footnotetext{
${ }^{15}$ See Flyvbjerg 2006 or Silverman 1993 for generalization on the basis of single cases.

${ }^{16}$ Groenten means 'vegetables', but this is, in fact, the misspelt intended word groeten 'greetings'. This error is meant to capture the limited writing skills of the character using this word, namely, Jan Debruycker, who concludes his formal handwritten letters to the Belgian King with groenten uit Balen 'vegetables from Balen' instead of writing groeten uit Balen 'greetings from Balen'.
} 
was to paint an authentic picture of the working class of a few decades ago:

[De film] speelt zich om te beginnen al in de jaren 70 af, waar dat er nog veel meer dialect gesproken werd dan nu ... zeker in die sociale klasse, dus ik heb daar [aan de keuze voor dialect] nooit aan getwijfeld. da moest gewoon, da kon nie anders. ${ }^{17}$

[F]irst of all it [that is, the film] takes place in the 1970s, when dialect was still spoken much more often than it is today ... especially in that social class, so I never doubted that [that is, the choice for dialect]. It just had to be like that, there was no other option.

That said, there are a couple of (secondary) characters whose language use diverges from the dialectal baseline, and intentionally so. One of them is the engineer working at the Vieille Montagne factory, whose short appearance in the film we have transcribed in the following extract.

Extract $1 .^{18}$ Across the bridge! January 8,1971 , the Vieille Montagne factory in Balen-Wezel. A group of dissatisfied workers, led by Piet Poppeliers, heads towards the factory's engineer. They would like him to go to the board of directors to discuss their dissatisfaction with wages (workers at other factories are earning 10 francs per hour, while they are only earning eight francs). Emphases are underlined, the " $=$ " sign indicates latching. An English translation is given in italics below each line.

1 workers: ((luid kabaal)) ((loud noise))

\footnotetext{
${ }^{17}$ Frank Van Mechelen in interview with Sarah Van Hoof, February 2, 2012.

${ }^{18}$ The transcript of this scene is ours. Film produced by Skyline Entertainment \& VRT, director Frank Van Mechelen, scenario Guido Van Meir and Walter Van den Broeck, 2011. Copyright holder is Skyline Entertainment.
} 
2

3 Piet:

4 Kris:

5 Piet:

6

7 engineer:

8

9 ?:

10

11 engineer:

12

13 Piet:

14

15

16 engineer:

17

18 Kris:

19

20 Marcel: ((ondertussen:))

((in the meantime:))

HOW JOM!

HO MAN!

mannekes!

guys!

HOW!

HO!

((gejoel houdt niet op))

((cheering does not stop))

((overstemd door kabaal)) HEY HEY HEY! KALM!

((overwhelmed by row)) HEY HEY HEY! CALM!

KALM!

CALM!

kalm kalm!

calm calm!

((kabaal verstomt, iedereen zwijgt))

((row diminishes, everybody silent))

kalm. (.) dad is al'maal goed en wel, maa wa kan ik

calm down. (.) that's all fair and well, but what can I daaraan doen.

do about it.

gaa kunt no boven goan. en zeggen da ons geduld, you can go upstairs. and tell them that our patience, naa oep is. gaa zaa ingenieur is now over. you're engineer godverdoeme nor aa geun ze leusteren! goddamn it they will listen to you!

((nee schuddend)) ik 'eb daarboven niks te vertellen. ((shaking his head)) I've got nothing to say up there. dad is 'et werk van uw délégués. that's the work of your delegates.

((grimas makend)) ons délégués zen twieë handen ((making grimace)) our delegates are hand in glove oep ieënen boik me(t) te boazen da wette gaa ok. with the bosses you know that too.

heui. 


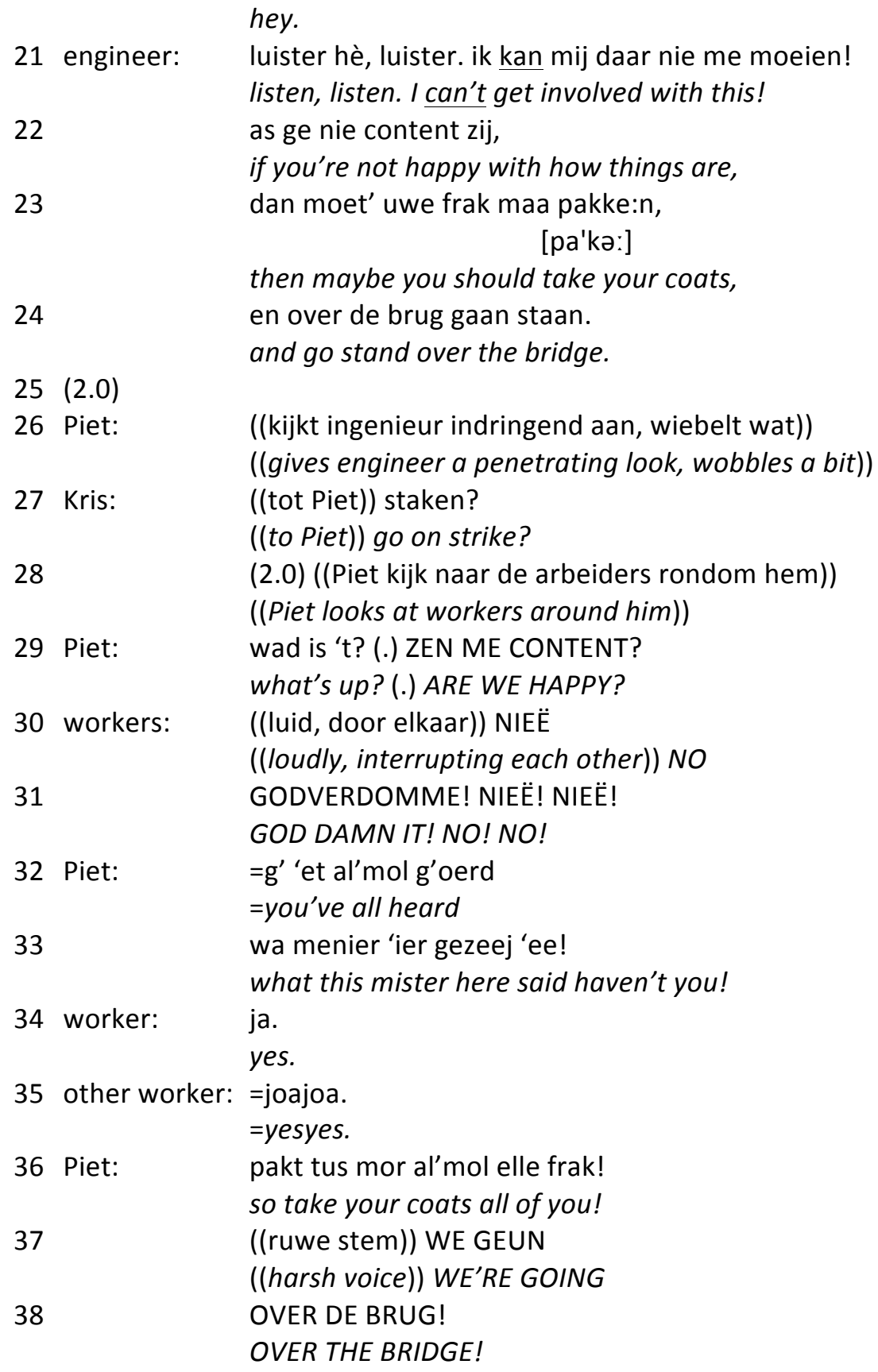


((luid kabaal, de arbeiders vertrekken))

((loud row, workers leaving))

40 engineer:

((overstemd)) ja maa wacht-wacht-wacht!

((drowned out)) yes but wait-wait-wait!

41

ja maa wacht! da's ook nie(d) de bedoeling hé!

42

yes but wait! that's not what I meant eh!

((ingenieur blijft bedremmeld achter

42

((engineer stays behind embarrassedly

met de vakbondsafgevaardigden, Frans en Marcel))

43 Frans:

with the delegates, Frans and Marcel))

onNOEËzeleir! ((draait zich geërgerd om))

you FOOL! ((turns around in irritation))

In the social hierarchy of the Vieille Montagne factory, the engineer takes up a higher position. This is why the workers turn to him with their grievances: They know that they have a better chance to be heard if the engineer were to voice their concerns to the board of directors. The higher position of the engineer is signaled by a number of semiotic contrasts. On a visual level, it has to be noted that the engineer's outfit is markedly different from those of the workers (see pictures 1 and 2): $\mathrm{He}$ is wearing glasses, a shirt and a tie, and a waistcoat with a beige mackintosh over it. The workers are all wearing the same blue-colored workman's clothes.

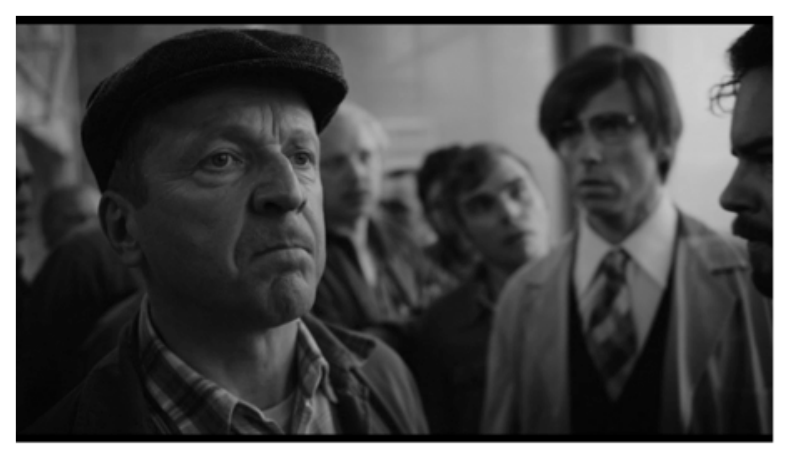

Picture 1. Engineer (middle), surrounded by Piet (furthest left), Kris (furthest right) and the other workmen.

(http://www.groentenuitbalen.com/downloads.asp) 


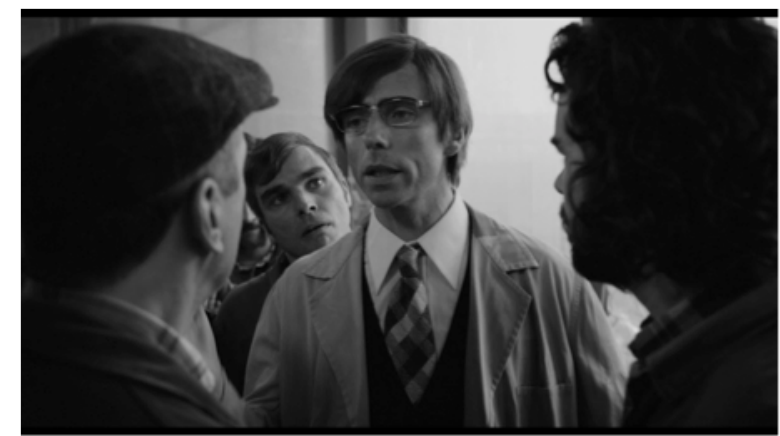

Picture 2. Piet (furthest left), the engineer (right),

Kris (furthest right) and the other workmen.

(http://www.groentenuitbalen.com/downloads.asp)

In addition to the visual contrast, the actors in this scene unmistakably create a linguistic contrast between the engineer and the workforce. Thus, the language of Piet, Kris, and Frans, the workers who have a turn at talk in this extract, is characterized by primary and secondary phonological dialect features (Taeldeman 2006) typical for the southern Campine (Belemans \& Goossens 2000):

- the half-close /e:/ is realized as diphthong [iə] (twieë 'two', line 18; ieëne 'one', line 19; nieë 'no', line 30, 31; menieër 'sir', line 33; see table 2 above);

- the half-close /o:/ is realized as diphthong [uə] ( $g^{\prime}$ oerd 'heard', line 32; onnoeëzeleir 'fool', line 43; see table 2 above);

- the diphthong $/ \varepsilon i /$ is produced as the long monophthong [a:] (gaa 'you', line 13, 14);

- the diphthong /œy/ is pronounced as [0: $\left.{ }^{\circledR}\right]$ (boik 'stomach', line 19) or [œ] (leusteren 'listen', line 15);

- the long /a:/ is produced as [0:] (goan 'go', line 13; boazen 'bosses', line 19) or [0] (al'mol 'all', line 32, 36; mor 'but', line 36). 
In comparison, the engineer's vowels are much more standard-like:

- he pronounces the half-close /o:/ as a Standard Dutch [o:] (ook 'also', line 41; see table 2 above);

- he realizes the long /a:/ consistently as a Standard Dutch [a:] (al'maal 'all', line 11; maa 'but', line 11; daaraan 'about that', line 12; daarboven 'up there', line 16; daar 'there', line 21; maa 'but', line 23; gaan 'go', line 24; staan 'stand', line 24).

From a structural point of view, his long, monophthongal realizations of /œy/ as [œ:] (in luister 'listen', twice on line 21) hover in-between the Brabantic dialectal pronunciation of that vowel (as [œ]) and the Standard Dutch, diphtongal realization of it ([œy]), which would warrant their categorization as tussentaal. His deletions of the word-final / $t$ / in words such as wa 'what' (versus Standard Dutch wat, line 11), nie 'not' (versus Standard Dutch niet, line 21) and me 'with' (versus Standard Dutch met, line 21) are classic markers of tussentaal (see table 1 above). The engineer's morphosyntactic and lexical choices likewise are typical for tussentaal:

- he addresses the workers with the nonstandard pronoun ge 'you' instead of Standard Dutch jij, but instead of pronouncing it with a dialectal vowel (gaa) he opts for a more standard pronunciation (with a sjwa, line 22; see table 1 above);

- similarly, he produces an intermediary form of the possessive pronoun used with that last noun (producing inflected uwe 'your', instead of uninflected Standard Dutch uw or inflected dialectal aawe, line 23);

- he realizes an enclitic form of the 2 nd person pronoun, namely moet(e) 'you have to' (line 23), instead of Standard Dutch moet je (see table 1 above);

- he selects a number of vernacular lexical items such as content 'satisfied' (a loan from French, line 22) and frak 'coat' (line 23).

In structural terms, therefore, the engineer is using tussentaal, but it is the nondialectal character of his language use that appears to be most meaningful here: In accordance with his higher social status, which is 
also expressed through other semiotic means (namely, his clothes and glasses), he expresses himself in a higher, that is, more standardized variety than the dialect of the factory workers, who occupy a lower social position. A subtle detail that contributes to this contrast is that the engineer realizes the phoneme $/ r /$ as the uvular trill $[R]$, while the workmen use an alveolar [r]. By selecting this originally French uvular rather than the original Flemish [r], which is part of his default speech style, the actor might be suggesting that his character is Frenchspeaking, or more precisely, bilingual in Dutch and French, which at the time of the narrative, in the early 1970s in Flemish Belgium, would certainly not be unimaginable. ${ }^{19}$ Also, his pronunciation of the word pakken 'catch' with a slightly prolonged and stressed last syllable, which is typical for French-speaking learners of Dutch, hints at phonological interference of French. ${ }^{20}$

Hence, the language use of the engineer in Groenten uit Balen reveals its full social meaning only when analyzed in situ and placed in its local social ecology: In a film where most characters are dialectspeaking workers, the engineer's tussentaal is first and foremost indexical of his higher social position in the Vieille Montagne factory; it also reflects a trait of the time, namely, that members of the elite and those who had enjoyed higher education in Flanders tended to be predominantly French-speaking.

In the previous example, language use that on a structural basis can be termed tussentaal indexes a social meaning traditionally associated with Standard Dutch. In the next example, we demonstrate that language use that is structurally very similar to the engineer's speech style in extract 1 can also carry meanings conventionally associated with dialect use.

\section{Tussentaal Functioning as Dialect.}

\footnotetext{
${ }^{19}$ The actor, Günther Lesage, usually plays his roles with an unmistakable alveolar [r]. See, for example, his recent roles in the sketch program Wat als? 'What if' on the TV channel 2Be (http://vtm.be/wat-als/, last accessed April 2014).

${ }^{20}$ See, for example, Hiligsmann \& Rasier 2007 for a description of prosodic transfer difficulties for French-speaking learners of Dutch.
} 
In our second example, taken from the 1984 series De burgemeester van Veurne 'The mayor of Furnes', we find one character that, on a linguistic level, diverges from the other characters in the series. This character is the mother of the protagonist, mayor Terlinck. In the next extract, she makes her first appearance in the series.

Extract $2 .^{21} \mathrm{~A}$ rich mister (The mayor of Furnes). Terlinck walks across the lawn between a couple of small farms. He runs into his mother.

1 mother: komt gij vandaag in Kokside doen?

[what] are you doing in Coxyde today?

2

' $t$ is niet uw gewone dag. kom binnen.

it's not your usual day. come in.

3 ik was bij de Kramse. die zoon is erg ziek.

I've just been to the Kramse. that son is very ill.

4 Terlinck: ja wad 'eeft ie?

yes what does he have?

5 mother: de dokter weet 'et niet.

the doctor doesn't know.

6 Terlinck: ah hij wil 'et nie zeggen zeker.

ah surely he doesn't want to tell.

7 mother: as ' $\mathrm{ij}$ ' $\mathrm{t}$ nie weet kan ' $\mathrm{ij}$ ' $\mathrm{t}$ nie zeggen!

if he doesn't know it he can't tell it!

8 Terlinck: en welke zoon is 'et.

and which son is it.

$9 \quad$ die magere die verleden jaar met een stok liep?

that scrawny one that walked with a stick last year?

10 mother: ja. Fernand. yes. Fernand.

11 Terlinck: ah. de teringlijder. hm? die haalt nieuwjaar nie meer. ah. the consumptive. hm? he won't make the new year. ze zouden ' $m$ trouwens beter naar een ziekenhuis in fact they'd better take him to a hospital.

${ }^{21}$ The transcript of this scene is ours. TV series (3 installments) produced by BRT, director Dre Poppe, scenario Johan Boonen after Georges Simenon, 1984. 
brengen. de kans is groot, datie de hele familie aansteekt there's a serious chance he infects the whole family.

14 mother: ((laag)) zieken'uis zieken'uis. ((low)) hospital hospital. ze zouden $\mathrm{u}$ is in een zieken'uis moeten steken! they should put you in a hospital some day! gij zou uw eigen moeder in e zieken'uis steken gij, you would put your own mother in a hospital, you, en uw [eigen vrouw!] and your [own wife!]

18 Terlinck: [moede::r!] ((volgt haar naar binnen)) [mothe::r!] ((follows her inside))

19 mother: (as) nen arme mens ziek is, dan willen ze d'r vanaf! (when) a poor man is ill, then they want to get rid of him! dan moet 'ij weg! ((schenkt koffie)) then he needs to go! ((pours coffee))

why have you come?

22 Terlinck: zo mor. om u te zien. just like that. to see you.

23 mother: 'oe gaat 'et me(t) Thérèse? how is Thérèse doing?

24 Terlinck: goed.

fine.

25 mother: en met Emilia? and Emilia?

26 Terlinck: $\mathrm{mhm}$. mhm.

27 mother: da's iemand die g' in e zieken'uis zou moeten steken. now that's someone you ought to put in a hospital. maa nee. e zieken'uis da's voor arme mensen. but no. a hospital's for poor people.

29 Terlinck: 't is beter voor haar. it's better for her.

30 mother: waarom. ze beseft nie eens waar $z^{\prime}$ is. why. she doesn't even know where she is.

31 Terlinck: ze beseft 'et wel! ((drinkt koffie)) 
she does know! ((drinks coffee))

32 mother: gij 'b zeker geen 'onger.

you're not hungry are you.

33 Terlinck: ((schudt nee))

((shakes his head))

34 mother: (ha) ge ga(at) toch een beetje garnalen meenemen.

(ha) but you are going to take some shrimps with you.

35 voor uw vrouw. kan $\mathrm{m}^{\prime}$ anders goed voorstellen

for your wife. could imagine quite well though

36 da ge $z$ ' 'ier of daar weggooit in een sloot.

you'd throw them away here or there in a ditch.

37 zijt ge nog altijd tevreden?

are you still happy?

38 Terlinck: ja moeder! ((zucht zacht))

yes mother! ((sighs softly))

39 mother: tussen al die rijke mensen?

between all these rich people?

40 Terlinck: ik zit nie(t) tussen rijke mensen.

I'm not between rich people.

41 mother: ik vind tat gij e rijke menieër zijt.

I think you are a rich mister.

42

en ' $k$ moet van rijke menieëren niks 'ebben.

and I don't want to have anything to do with rich misters.

' $k$ 'eb ze nie nodig. en zij 'ebben mij nie nodig.

I don't need them. and they don't need me.

toen uw vader en ik, dit huis kochten,

when your father and l, bought this house,

45

kostte maar duizend frang toen. eh.

only cost a thousand francs then. uh.

wa was 'k nu aan 't zeggen? waren al tien jaar getrouwd. what was I saying? had been married for ten years then. uw vader was garnalenvisser. en ik verkocht ze. your father was a shrimper. and I sold them. went by every door with my two baskets.

toe- (.) ah ja! ((gaat zitten))

whe- (.) oh yes! ((sits down)) 
toen we dit huis gekocht hadden. toen waren we blij! when we had bought this house. then we were happy! want we zouden nooit in een 'ospice terechtkomen! because we would never end up in a hospice! you were still at the little school then. ((music sets in)) en niemand kon weten,

da gij ne rijke meneer zou worden. that you would become a rich mister. en burgemeester, van Veurne. ((schenkt koffie)) and mayor, of Furnes. ((pours coffee))

This scene is part of the narrative exposition and provides background information on the main characters, as is typical for the first episode of a series. In the preceding scenes, the audience was introduced to the protagonist Joris Terlinck, who isn't just the mayor of Veurne but also the owner of a profitable cigar factory, and who finds his power besieged by the catholic opposition in his town. It soon turns out that Terlinck has a cold and calculating mind. His fortune comes from his marriage of convenience to the ailing Thérèse, a rich architect's daughter, and from the inheritance left to him by a rich widow. Terlinck used to be her bookkeeper and became a beneficiary under her will in a not entirely legitimate way.

In this scene, Terlinck's mother summarizes this biographical information explicitly: He has become a "rich mister" (line 41). The audience now finds out that this was not always the case. In a monologue (lines 44-52) which is redundant for Terlinck himself but clarifying for the viewers, the mother adds that the Terlinck family is quite lowborn, and that Terlinck is the child of a poor shrimper. This information is also visually illustrated through the contrast between Terlinck's exquisite mansion, in which a number of the preceding scenes were set, and the starkly furnished, dark fisherman's cottage, where he pays a visit to his mother (see pictures 3-6).

This social contrast, we would like to argue, is also indexed linguistically. Thus, Terlinck's mother's language use deviates somewhat from that of the other, relatively more standard speaking characters. 
From a structural point of view, it is tussentaal: With the exception of one minor character, Mother Terlinck's language displays the highest rate of tussentaal variants and of (primary and secondary) dialect variants in the series, whereas the frequency of occurrence of the latter in her speech is too low to characterize it as a full-fledged dialect.

A particularly salient dialectal variant is the (originally MiddleDutch) monophthong [i], which she uses instead of the Standard Dutch diphthong [ $\varepsilon$ i] in the place name Kokside 'Coxyde' (line 1) and which is a typically West-Flemish dialect feature (Devos \& Vandekerckhove 2005:43-44). Kokside seems to provide what Coupland (2007:124) has termed a "phono-opportunity": The place name is particularly apt for "showcasing" a dialectal vowel that indexically reinforces the denotational link with the West-Flemish coastal town. In addition, Mother Terlinck produces two dialectal diphthongs [iə] instead of Standard Dutch monophthongal [e:] (menieër 'mister', menieëren 'misters', line 41, 42; see table 2). Note, however, that this dialect marker does not occur in every potential environment: In line 54, Mother Terlinck produces meneer with a Standard Dutch [e:]; the same holds for twee (line 48) and burgemeester (line 55). The old woman's speech can therefore hardly be called truly dialectal. It is mainly her use of the typical tussentaal markers that makes her way of speaking stand out from that of the other characters. Thus, she is the only character in this first episode that uses nonstandard forms of address, gij/ge 'you' (line 1, 34, 36); all other characters without exception address one another using the standard forms je 'you' and $u$ 'you'.

Other features generally regarded as typical for tussentaal include:

- the use of t-apocope (for example, nie, line 6; see table 1);

- h-procope ('ij 'he', line 20; zieken'uis 'hospital', line 14, 15; see table 1);

- elisions ( $g[e]$ in 'you in', line 27; $m[e]$ anders 'me otherwise', line 35; z[e] 'ier 'them here', line 36);

- inflected articles (nen arme mens instead of standard een arme mens 'a poor man', line 19; ne rijke meneer instead of standard een rijke meneer, line 54; see table 1 ). 
Again, these features are not used consistently, however. Sometimes Mother Terlinck does produce word-final [t] (for instance, lines 41, 48) and onset [h] (line 44); similarly, sometimes she does not inflect her adnominals (for example, de dokter instead of nonstandard den dokter 'the doctor', line 5). In other words, standard and nonstandard realizations alternate.

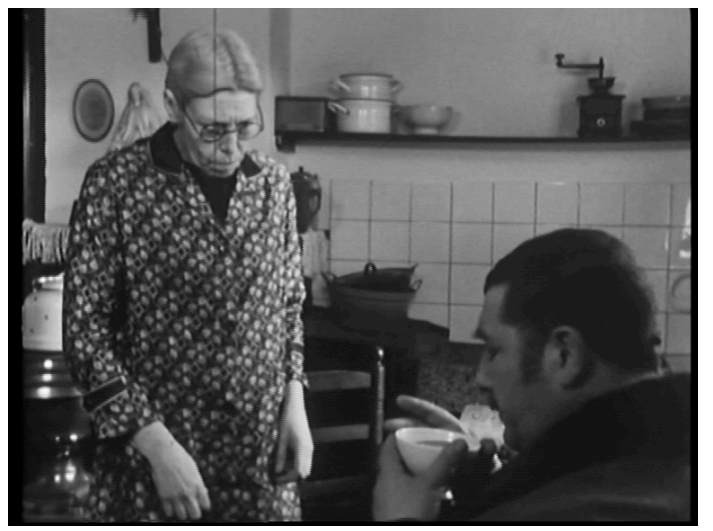

Picture 3. Terlinck having coffee at his mother's.

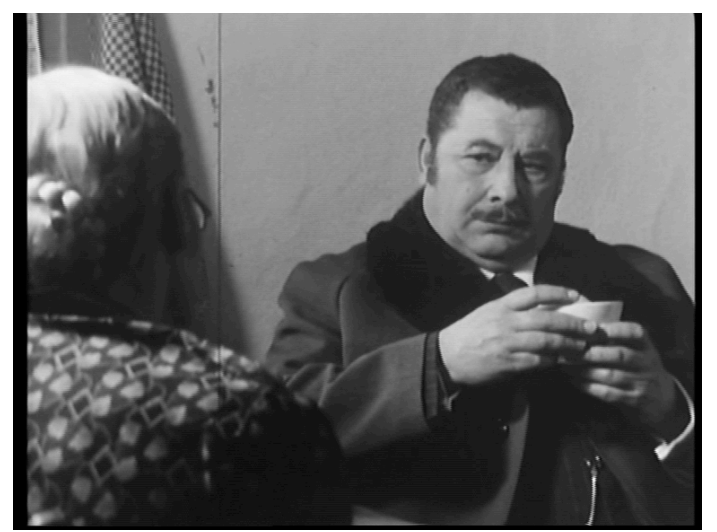

Picture 4. Terlinck having coffee at his mother's. 


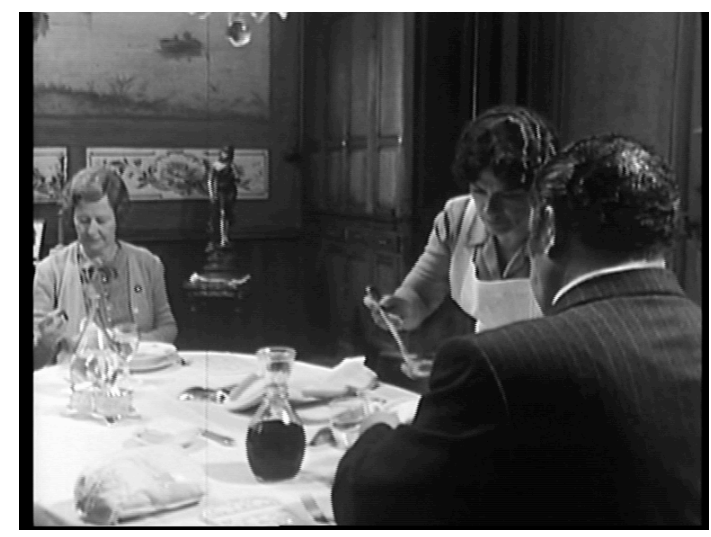

Picture 5. Terlinck having dinner with Thérèse at home.

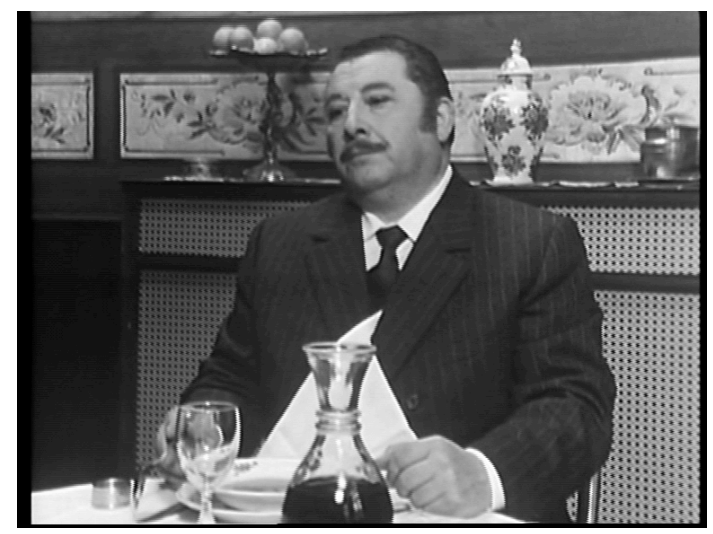

Picture 6. Terlinck having dinner with Thérèse at home.

On a structural level, Mother Terlinck's language use in extract 2 is different from the engineer's in extract 1 , but the two also have similarities. One difference, for example, is that the engineer consistently produces his tussentaal markers in a nonstandard way, 
whereas Mother Terlinck uses nonstandard features more eclectically. At the same time, both characters' speech styles have to be described as cases of tussentaal; they can hardly be called dialectal, and they also significantly diverge from Standard Dutch due to the presence of a number of nonstandard linguistic features. Structurally, then, it would be safe to categorize both characters' language use as tussentaal.

It would not be an exaggeration to claim that the actress playing Mother Terlinck is building a contrast between the rich misters of the series and herself, a poor fisherwoman. To this end she is utilizing both the topic of her conversation and the style of her language use. Thus, her speech contributes implicitly-indeed, indexically-to what she is trying to convey explicitly to Terlinck and to the viewer. Just as in extract 1 where linguistic means are recruited to convey a social gap between the engineer and factory workers, Mother Terlinck's language in extract 2 helps depict a social hierarchy. While Mayor Terlinck rose to the top of his hierarchy, his mother still finds herself at the bottom. However, unlike the engineer's tussentaal in extract 1, Mother Terlinck's tussentaal represents not the "higher" but the "lower" variety relative to the Standard Dutch spoken by the other characters in the series. Put differently, in extract 1 , the engineer's tussentaal is meaningful because of its nondialectal quality, which places the speaker higher in the local social hierarchy. In contrast, in extract 2, Mother Terlinck's tussentaal is meaningful because of its nonstandard quality, its deviation from the language of other, higher-placed characters. What structurally is the same kind of language use, namely, tussentaal, can thus be read as dialect or Standard Dutch depending on the circumstances in which it is produced.

\section{Discussion.}

On a structural level, extracts 1 and 2 adequately present tussentaal. But the engineer's tussentaal in extract 1 appears to carry overtones of Standard Dutch, in the sense that it is the higher, or more prestigious variety in that setting. Conversely, Mother Terlinck's tussentaal in extract 2 appears to evoke dialect use, in the sense of Bleichenbacher (2008:59): Instead of letting the woman speak an authentic dialect, which an elderly, socially and geographically non-mobile fisherwoman from Coxyde would have spoken in the period between the two world 
wars, the creators of the series and the actress have decided to use a substitute language that would only display interference from the evoked language, namely, the dialect. ${ }^{22}$ Through selectively incorporating dialect features, the fisherwoman's speech style conjures up social meanings typically associated with dialect use, such as rurality, old age, manual labor, and low social status. Similar to what Vandekerckhove \& Nobels (2010:667) have observed with regard to the chat language of Flemish teenagers, she is "us[ing] a dialect style without consistently using dialect."

The preceding paragraphs thus demonstrate that it is necessary to analyze language use in its "volle situationaliteit" [full situationality] (Slembrouck \& Van Herreweghe 2004:874). An analysis based solely on a frequency count of structural elements in many cases fails to tap into the actual meanings that linguistic elements come to evoke in situated interaction, so that a qualitative, context-sensitive, interpretive analysis is needed to unlock what linguistic features in different environments can mean. A closer look at the two extracts reveals that what can be called tussentaal from a structural point of view often turns out to be something quite different seen from fictional characters' perspectives, to the extent that it may have to be understood as dialect or Standard Dutch. Although different linguistic strategies (tuning up in the engineer's case, tuning down in the fisherwoman's case) may exhibit considerable structural overlap, the effect they produce may be quite

${ }^{22}$ This evocation technique is frequently deployed in Hollywood films. In Schindler's List (1993), for example, which is set in Krakow and in the neighboring concentration camp Auschwitz in nazi-occupied Poland, the actors speak English with a Polish, German or Yiddish accent to evoke the Polish, German, and Yiddish of the historical figures they impersonate (Bleichenbacher 2008). Similarly, the actors in the screen adaption of Gabriel Garcia Márquez's best-selling novel Love in the Time of Cholera (2007), set in 19th century South America, speak English with a Spanish accent even if many of them are highly fluent Spanish speakers. Thus the producers avoid dialogues in other languages, which would have to be subtitled for the broad monolingual English audience (see Bleichenbacher 2008:59ff.). In the Allo Allo series (BBC, 19821992), this evocation technique is used for comical effect: French, German, Italian, and learner accents are used in portraying French citizens and members of the Resistance, German and Italian soldiers, and others. 
different, to the point of evoking diametrically opposed indexical meanings. Tussentaal may even pose as the standard variety it is so often seen to be but a crummy or maladroit replacement for.

Viewing tussentaal as a particular register, our data effectively illustrate what Agha (2005:47) argues is a characteristic of all register use, namely, that "effects of register token use are not always consistent with the stereotypic values associated with the register's form types." Tussentaal may evoke a range of stereotypic values (see above), but the effects of its use in particular ecologies may be entirely different. Tussentaal's bi- or multivalency (Woolard 1998) might, at least in part, account for its persistent structural unpredictability (see above): Whereas its general contours are more or less stable (it consists of a number of elements that distinguish it from Standard Dutch but are not strictly dialectal), its actual realization varies, most probably depending on speakers' routine speech style, their relationship with others, the activity type, its keying, and the local linguistic ecology. For tuning up and tuning down relative to other participants' ways of speaking, speakers have a number of options available to them, at every level of linguistic structure (phonology, morphology, syntax, and lexicon). Different choices at any of these levels may sometimes trigger very subtle differences (see, for example, the engineer's uvular trill in extract 1 , which is not a regular ingredient of tussentaal, but which is highly meaningful in this particular context).

In any case, it is clear that tussentaal can hardly be attributed context-independent or essential meanings, such as rebelliousness, naturalness, a conspicuously relaxed character, or anti-authoritarian resentment. All of these meanings may be communicated through tussentaal, and in some contexts (such as some media genres) they may have become enregistered, stereotypic attributes of tussentaal. However, the point is that the meaning of a particular set of linguistic forms is, in principle, dependent on local linguistic ecologies and cannot be presumed to hold across the board: The engineer and the fisherwoman above are neither rebellious nor intentionally sloppy, nor are they taking any anti-authoritarian stance.

We suggest that on many occasions, including nonfictional ones, speakers produce meanings through tussentaal that go beyond its stereotypical appreciation. In principle, this dependency between forms 
and ecologies is a necessary requirement for speaking of "informal Standard Dutch" altogether (see section 2). If tussentaal were essentially to convey stances such as rebelliousness and conspicuous relaxation in a context where dominant expectations put a premium on Standard Dutch, then the latter variety could only be an emblem of obedience, compliance with expectations, and non-relaxedness, complicating its use as an informal variety in casual conversation. Such determinisms can be avoided if we allow tussentaal as well as Standard Dutch and dialect to be much more multi-dimensional or polyvalent in their indexical significance, and, in particular, when we liberate tussentaal from the small harnessed set of social meanings it has been allowed to index as the 'anti-language' within an ideology of standardization. Doing so can help reconsider current claims that tussentaal is one of the symptoms of a pan-European destandardization process.

\section{Destandardization?}

The term destandardization mostly applies to changing attitudes toward linguistic normativity, which are not only observed in Flanders but also elsewhere in Europe. The currently most widely used definition is the one formulated by Coupland \& Kristiansen (2011:28), who take this term

[T]o refer to a possible development whereby the established standard language loses its position as the one and only 'best language'. ... Such a development would be equal to a radical weakening, and eventual abandonment, of the 'standard ideology' itself.

For Flanders in particular, van der Horst (2010:23) has hypothesized a process of destandardization, pointing at (among other things) a "widening of the norm," "increased tolerance," "decreasing fear of variation and 'foreign elements'," etc., while Willemyns (2013:245-246) has noticed (both for the Netherlands and for Flanders) "an important attitudinal change [that] is upgrading the prestige of intermediate varieties: people seem to take them more seriously and their use is more commendable." Grondelaers \& van Hout (2011) and Grondelaers 
et al. (2011) have powerfully argued, on the basis of experimental attitude research, that Flanders experiences a "standard language vacuum" (Grondelaers \& van Hout 2011): Since the erstwhile imported Standard Dutch is all but a virtual variety, exclusively used by Flemish news anchors, and given that no other way of speaking is consistently identified as "best" or most "beautiful" by subjects in the experiments invited to judge the regionally colored but formal spoken Dutch of teachers, no stand-in appears to be ready to replace the virtual norm (Grondelaers et al. 2011:217-218).

It is undeniable that much more nonstandard language use can be observed in contexts traditionally associated with standard language use (for example, audio-visual media, school, etc.). It is also true that more and more language experts and/or exemplary speakers (authors, politicians, TV presenters, sociolinguists, official authorities) have contributed to an ambivalent attitude toward standard language use, in Flanders as elsewhere, through their explicit criticism of linguistic purism (in the case of sociolinguists) or their abundant recruitment of nonstandard language use in their writing, as well as their oratory or public communication (all others; compare Grondelaers \& van Hout 2011). In addition, the standard language itself has been increasingly portrayed as undesirably intellectualist, posh, and otherwise "uncool" (see Mugglestone 2003:280 on how Received Pronunciation in Britain has come to be seen as "talking posh" rather than "talking proper").

In spite of these changes, however, a number of facts suggest that linguistic standardization, as a widespread, historically rooted view on the use, organization, and application of language (see Bauman \& Briggs 2003), may not have lost all of its feathers yet. First of all, the sheer increase in nonstandard language use in the public sphere, and on television in particular, ought not, in our view, be taken as an undiluted sign of the dwindling hold of standardization on the public mind or automatically be seen as a denial of standardization (compare Grondelaers \& Kristiansen 2013:10). A quantitative increase does not by itself change the conditions within which these quantities are produced (compare Coupland 2014:90). To be sure, while media allow for much more linguistic diversity in drama and comedy, shows, and other entertainment, the more "important" and authoritative genres (such as the news) are still the exclusive domain of the standard variety. Agha 
(2003:264) argues in this respect that standard language use may have to be less widespread than nonstandard language use in order for the former to retain social prestige (complete diffusion amounting to the devaluation of the standard).

But also the empirical data we have discussed indicate that nonstandard language use does not simply contradict but may even depend on the existence of a standard language ideal. The engineer and the fisherwoman signal status differences through inserting in their speech linguistic features (next to postural or sartorial ones) that have been firmly enregistered as "high" or "low" in the symbolic hierarchy that the process of linguistic standardization has come to construct (Agha 2003, Bauman \& Briggs 2003). They are, in other words, orienting to a frame of standardization in which it makes sense to treat dialectal and standard features as hierarchically organized and to recruit them for flagging personae or stances that are considered higher or lower within that frame.

What these characters do, therefore, makes no sense unless it is viewed as constructed for a framework that producers and consumers of the discourse take for granted or see as the baseline of their linguistic ecology, namely, the framework of linguistic standardization. Seen from this perspective, tussentaal in Flemish telecinematic discourse in large part reproduces at the same time as it requires an ideology of standardization, rather than, as often suggested, announcing its approaching demise (see Grondelaers \& Speelman 2013 for an analysis that goes beyond this traditional view). This also puts into perspective why many actors accused of "succumbing" to tussentaal in the fiction series they play in quite often turn out to be ardent supporters of Standard Dutch in non-fictional settings (see Van Hoof, in press). ${ }^{23}$

For these reasons, we think it would be more useful, by analogy

\footnotetext{
${ }^{23}$ Many of the actors interviewed by Van Hoof (2013) explicitly stressed the importance of a good Standard Dutch competence and pointed out that in acting school they received thorough language training. For example, they learned how to produce a proper alveolar [r] (instead of the uvular trill $[R]$ - see above). Many of them also pointed out that for TV genres other than fiction, especially for the news, they only considered Standard Dutch the appropriate language.
} 
with analyses of late modernity (Bauman 2000, Giddens 1991), to characterize the current linguistic situation in Flanders as a case of LATE STANDARDIZATION rather than destandardization. This indicates that while linguistic standardization has been challenged by socio-economic processes (globalization, migration), changes within public broadcasting that open up markets for nonstandard language use, as well as by linguists who explicitly criticize prescriptivist attitudes, it still appears to set the guidelines for much language use on television, and probably also on the other side of the screen. The term late standardization alludes to the fact that standard and vernacular language use are currently being reconfigured, with the latter becoming more prominent in contexts and genres where the standard language used to be de rigueur, while the tension between standardizing and vernacularizing forces is intensifying and their relationship becoming more complex (Coupland 2010). At the same time, conceptualizing the present situation as a case of late standardization captures the fact that this tension is not entirely new, and that in some contexts, vernacular language use has always had (sometimes even considerable) presence.

Obviously, as a product of human ambition, an ideology of standardization is not impervious to change or an eventual collapse. However, the signs of such a demise, or at least of the diminishing relevance of the standard language for fiction series, would have to include, among other things, a less systematic distribution of dialect and standard language features over characters, situations, and stances that are hierarchically ordered. A fundamental linguistic regime change may also have to imply the nonconspicuous switches to a more dialectal way of speaking when character traits such as beauty, politeness, and refined manners are to be displayed; or, the inconspicuous use, by the same set of characters, of idiomatic dialect and standard language for similar purposes and in similar circumstances. While TV fiction and film would seem to be perfect venues for conjuring up worlds without standard languages, the persistent influence of linguistic standardization is shown in a wide range of contemporary fantasy TV series and films, such as Game of Thrones or The Hobbit. Game of Thrones typically illustrates hierarchical differences between and also within various aristocratic families not only by the lustre of their lodgings and clothes, but also by the amount of nonstandard language features in their 
speech. Thus, even in a fantasy world, standardization is our guiding light.

\section{Conclusion.}

In this article, we have tried to demonstrate that the meaning of linguistic features needs to be established in situ, and that what looks like tussentaal at the structural level, in specific contexts of use must be interpreted as dialect or Standard Dutch. Consequently, the popularity of tussentaal and its ascendance in Flemish telecinematic discourse may effectively hide that in many cases, much use of this variety is meant and interpreted as Standard Dutch or dialect. Fictional characters' moves up and down the linguistic ladder show that they orient to, rather than ignore, a long-standing standardization ideology in which these moves make sense. Consequently, the occurrence of tussentaalor mixed Dutch-is not necessarily at loggerheads with linguistic standardization, but even reproduces it in accepting that it defines the limits of the linguistically possible. This complicates tussentaal's representation as a clear symptom of destandardization. Instead, this view calls for a perspective of late standardization, in which standardizing and vernacularizing forces condition, rather than cancel one another.

\section{REFERENCES}

Absillis, Kevin, Jürgen Jaspers, \& Sarah Van Hoof (eds.). 2012. De manke usurpator. Over Verkavelingsvlaams. Gent: Academia Press.

Agha, Asif. 2003. The social life of cultural value. Language and Communication 23. 231-273.

Agha, Asif. 2005. Voice, footing, enregisterment. Journal of Linguistic Anthropology 15. 38-59.

Agha, Asif. 2007. Language and social relations. Cambridge: Cambridge University Press.

Androutsopoulos, Jannis. 2012. Introduction: Language and society in cinematic discourse. Multilingua 31. 139-154.

Auer, Peter. 2005. Europe's sociolinguistic unity, or: A typology of European dialect/standard constellations. Perspectives on variation: Sociolinguistic, historical, comparative, ed. by Nicole Delbecque, Johan van der Auwera, \& 
Dirk Geeraerts, 8-42, Berlin-New York: De Gruyter.

Bauman, Richard, \& Charles Briggs. 2003. Voices of modernity. Language ideologies and the politics of inequality. Cambridge: Cambridge University Press.

Bauman, Zygmunt. 2000. Liquid modernity. Cambridge: Polity Press.

Belemans, Rob, \& Jan Goossens. 2000. Woordenboek van de Brabantse dialecten. Deel III: Inleiding en Klankgeografie. Assen: Van Gorcum.

Barnard, Benno. 1999. Het groot nationaal dichtertje. NRC Handelsblad, February 5, 1999.

Bezooijen, Renée van. 2004. Dialectattitudes in Vlaanderen en Nederland. De Caluwe, Devos, Van Keymeulen, \& De Schutter 2004, 777-788.

Bleichenbacher, Lukas. 2008. Multilingualism in the movies. Hollywood characters and their language choices. Tübingen: Francke Verlag.

Blommaert, Jan. 2005. Discourse. A critical introduction. Cambridge: Cambridge University Press.

Bourdieu, Pierre. 1991. Language and symbolic power. Cambridge: Polity Press.

Bucholtz, Mary. 2003. Sociolinguistic nostalgia and the authentication of identity. Journal of Sociolinguistics 7. 398-416.

Cajot, José. 2012. Waarom het Verkavelinsgsvlaams onvermijdelijk was. De ontwikkeling van een informele omgangstaal in Vlaanderen. Absillis, Jaspers, \& Van Hoof 2012, 39-66.

Camps, Hugo. 2011. Taal. De Morgen, July 28, 2011.

Coupland, Nikolas. 2009. The mediated performance of vernaculars. Journal of English Linguistics 37. 284-300.

Coupland, Nikolas. 2010. Language, ideology, media and social change. Performing the self, ed. by Karen Junod \& Didier Maillat, 127-151. Tübingen: Gunter Narr.

Coupland, Nikolas, \& Tore Kristiansen. 2011. Critical perspectives on language (de)standardisation. Standard languages and language standards in a changing Europe, ed. by Tore Kristiansen \& Nikolas Coupland, 11-38. Oslo: Novus.

De Caluwe, Johan. 2002. Tien stellingen over functie en status van tussentaal in Vlaanderen. Taalvariatie en taalbeleid. Bijdragen aan het taalbeleid in Nederland en Vlaanderen, ed. by Johan De Caluwe, Dirk Geeraerts, Sjaak Kroon, Virginie Mamadouh, Ronald Soetaert, Luc Top, \& Ton Vallen, 57-67, Antwerpen-Apeldoorn: Garant.

De Caluwe, Johan. 2009. Tussentaal wordt omgangstaal in Vlaanderen. Nederlandse Taalkunde 14. 8-25.

De Caluwe, Johan, Magda Devos, Jacques Van Keymeulen, \& Georges De Schutter (eds.). 2004. Taeldeman, man van de taal, schatbewaarder van de 
taal. Gent: Academia Press.

De Caluwe, Johan, \& Evelien Van Renterghem. 2011. Regiolectisering en de opkomst van tussentaal in Vlaanderen. Taal en Tongval 63. 61-77.

De Schryver, Johan. 2012. Het einde van de tussentaal en de Vlaamse standaardtaaldiscussie. Absillis, Jaspers, \& Van Hoof 2012, 141-165.

Devos, Magda, \& Reinhild Vandekerckhove. 2005. West-Vlaams. Tielt: Lannoo.

Deprez, Kas. 1981. Naar een eigen identiteit: resultaten en evaluatie van tien jaar taalsociologisch en sociolinguistisch onderzoek betreffende de standaardtaal in Vlaanderen. Leuven, Belgium: K.U.Leuven dissertation.

Deprez, Kas. 1999. Flemish Dutch is the language of the Flemings. Belgian Journal of Linguistics 13. 13-52.

De Wever, Bart. 2007. Wie echt cool is, heeft Bert Anciaux niet nodig. De Morgen, July 16, 2007.

Eckert, Penelope. 2012. Three waves of variation study. The emergence of meaning in the study of sociolinguistic variation. Annual Review of Anthropology 41. 87-100.

Elsaesser, Thomas, \& Malte Hagener. 2010. Film Theory. An introduction through the senses. New York-London: Routledge.

Fairclough, Norman. 1992. Discourse and social change. Cambridge: Polity Press.

Florquin, Joos. 1965. Hier spreekt men Nederlands. Een dialoogtekst voor de hogere cyclus, gebruik dit in de klas! Bouw XI, 1. 22-23.

Flyvbjerg, Bent. 2006. Five misunderstandings about case-study research. Qualitative Inquiry 12. 219-245.

Geeraerts, Dirk. 1998. VRT-Nederlands en soap-Vlaams. Nederlands Van Nu, 46. 75-77.

Geeraerts, Dirk. 2001. Everyday language in the media. The case of Belgian Dutch soap series. Sprache im Alltag. Beiträge zu neuen Perspektiven in der Linguistik Herbert Ernst Wiegand zum 65. Geburtstag gewidmet, ed. by Andrea Lehr, Matthias Kammerer, Klaus-Peter Konerding, Angelika Storter, Gaja Thimm, \& Werner Wilski, 281-291. Berlin-New York: Walter de Gruyter.

Geeraerts, Dirk, Stef Grondelaers, \& Dirk Speelman. 1999. Convergentie en divergentie in de Nederlandse woordenschat. Amsterdam: Meertensinstituut.

Geeraerts, Dirk, \& Gert De Sutter. 2003. 'Ma wa zegdegij nu? Da kanekik nie verstaan zelle'. Taalgedrag, taalbeleid en taalattitudes in Vlaanderen. Waar gaat het Nederlands naartoe? Panorama van een taal, ed. by Jan Stroop, 54-64, Amsterdam: Bert Bakker.

Ghyselen, Anne-Sophie. 2011. Structuur en dynamiek van diaglossische 
taalrepertoria. Studies van de BKL 6.

Giddens, Anthony. 1991. Modernity and Self-identity. Self and Society in the Late Modern Age. Stanford CA: Stanford University Press.

Grondelaers, Stefan, \& Tore Kristiansen. 2013. On the need to access deep evaluations when searching for the motor of standard language change. Kristiansen \& Grondelaers 2013, 9-52.

Grondelaers, Stefan, \& Roeland van Hout. 2011. The Standard Language Situation in the Low Countries. Journal of Germanic Linguistics 23. 199243.

Grondelaers, Stefan, Roeland van Hout, \& Dirk Speelman. 2011. A perceptual typology of standard language situations in the Low Countries. Standard languages and language standards in a changing Europe, ed. by Tore Kristiansen \& Nikolas Coupland, 199-222. Oslo: Novus.

Grondelaers, Stefan, \& Dirk Speelman. 2013. Can speaker evaluation return private attitudes towards stigmatised varieties? Evidence from emergent standardisation in Belgian Dutch. Kristiansen \& Grondelaers 2013, 171192.

Haugen, Einar. 1972. The ecology of language. Stanford, CA: Stanford University Press.

Hendrickx, Ruud. 1998. Taalcharter. http://www.vrt.be/taal/taalcharter. Last accessed April 2014.

Hertmans, Stefan. 2012. Onzin, onzinnig en onzindelijk. De Standaard, August 31, 2012.

Hiligsmann, Philippe, \& Laurent Rasier. 2007. Prosodic transfer from L1 to L2. Theoretical and methodological issues. Nouveaux Cahiers de Linguistique Française 28, 41-66.

Horst, Joop van der. 2008. Het einde van de standaardtaal. Amsterdam: Meulenhoff.

Horst, Joop van der. 2010. Het einde van de standaardtaal in België. Liever meer of juist minder? Over normen en variatie in taal, ed. by Els Hendrickx, Karl Hendrickx, Willy Martin, Hans Smessaert, William Van Belle, \& Joop van der Horst, 15-25. Gent: Academia Press.

Janssens, Guido, \& Ann Marynissen. 2005. Het Nederlands vroeger en nu. Leuven: Acco.

Jaspers, Jürgen. 2001. Het Vlaamse stigma. Over tussentaal en normativiteit. Taal en Tongval. 53. 129-153.

Jaspers, Jürgen. 2011. Strange bedfellows. Appropriations of a tainted urban dialect. Journal of Sociolinguistics 15. 493-524.

Jaspers, Jürgen, \& Frank Brisard. 2006. Verklaringen van substandaardisering. Leuvense Bijdragen. 95. 35-70

Jaspers, Jürgen, \& Sarah Van Hoof. 2013. Hyperstandardisation in Flanders: 
extreme enregisterment and its aftermath. Pragmatics 23. 331-359.

Kristiansen, Tore, \& Stefan Grondelaers (eds.). 2103. Language

(de)standardisation in late modern Europe. Oslo: Novus.

Lybaert, Chloé. 2011. Hoe percipieert een taalkundige leek het Vlaamse taallandschap? Handelingen van de Koninklijke Zuidnederlandse

Maatschappij voor Taal- en Letterkunde en Geschiedenis 64. 123-146.

Mugglestone, Lynda. 2003. Talking proper. The rise of accent as a social symbol. Oxford: Oxford University Press.

Mühlhäusler, Peter. 1996. Linguistic ecology: Language change and linguistic imperialism in the Pacific region. London: Routledge.

Notte, Johan, \& Marie Scheirlink. 2007. Lui Vlaams. Interview met Johan Taeldeman. De Nieuwe Gemeenschap 4. 5-8.

Piazza, Roberta, Monika Bednarek, \& Fabio Rossi (eds.). 2011. Telecinematic discourse. Approaches to the language of films and television series. Amsterdam: John Benjamins.

Plevoets, Koen. 2008. Tussen spreek- en standaardtaal. Een corpusgebaseerd onderzoek naar de situationele, regionale en sociale verspreiding van enkele morfosyntactische verschijnselen uit het gesproken BelgischNederlands. Leuven, Belgium: K.U. Leuven dissertation.

Plevoets, Koen. 2009. Verkavelingsvlaams als de voertaal van de verburgelijking van Vlaanderen. Studies van de BKL/Papers of the Linguistic Society of Belgium, ed. by Svetlana Vogeleer, Frank Brisard, Philippe DeBrabanter, Patrick Dendale, \& Bert LeBruyn. Available at http://webh01.ua.ac.be/linguist/sbkl/Vol4.htm.

Plevoets, Koen, Dirk Speelman, \& Dirk Geeraerts. 2007. A corpus-based study of modern colloquial 'Flemish'. Germanic language histories 'from below' (1700-2000), ed. by Stephan Elspass, Nils Langer, Joachim Scharloth, \& Wim Vandenbussche, 179-188, Berlin: Mouton De Gruyter.

Queen, Robin. 2004. 'Du hast jar keene Ahnung': African American English dubbed into German. Journal of Sociolinguistics 8. 515-537

Rampton, Ben. 2006. Language in late modernity. Interaction at an urban school. Cambridge: Cambridge University Press.

Reynebeau, Marc. 2006. De Vlamingen begrijpen elkaar nog altijd niet. De Standaard, June 11, 2006.

Richardson, Kay. 2010. Television dramatic dialogue. Oxford: Oxford University Press.

Rys, Kathy, \& Johan Taeldeman. 2007. Fonologische ingrediënten van Vlaamse tussentaal. Tussen taal, spelling en onderwijs, ed. by Pol Cuvelier, Rita Rymenans, Sandra Dominiek, \& Peter Van Petegem, 1-9. Gent: Academia Press.

Silverman, David. 1993. Interpreting qualitative data. London: Longman. 
Slembrouck, Stef, \& Mieke Van Herreweghe. 2004. Teletekstondertiteling en tussentaal. De pragmatiek van het alledaagse. De Caluwe, Devos, Van Keymeulen, \& De Schutter 2004, 853-876.

Taeldeman, Johan. 1992. Welk Nederlands voor Vlamingen? Spieghel Historiael, 33. 9-28.

Taeldeman, Johan. 2006. Polarization revisited. Language variationEuropean perspectives, ed. by Frans Hinskens, 233-248, Amsterdam: John Benjamins.

Taeldeman, Johan. 2008. Zich stabiliserende kenmerken in Vlaamse tussentaal. Taal en Tongval 60. 26-50.

Van Gijsel, Sophie, Dirk Speelman, \& Dirk Geeraerts. 2008. Style shifting in commercials. Journal of Pragmatics 40. 205-226.

Van Hoof, Sarah. 2013. Feiten en fictie. Een sociolinguïstische analyse van het taalgebruik in fictieseries op de Vlaamse openbare omroep (1977-2012). Antwerp, Belgium: University of Antwerp dissertation.

Van Hoof, Sarah, \& Jürgen Jaspers. 2012. Hyperstandaardisering. Tijdschrift voor Nederlandse Taal- en Letterkunde 108. 97-125.

Van Hoof, Sarah, \& Bram Vandekerckhove. 2013. Feiten en fictie. Taalvariatie in Vlaamse televisiereeksen vroeger en nu. Nederlandse Taalkunde 18. 3564.

Vandekerckhove, Reinhild. 2000. Structurele en sociale aspecten van dialectverandering. De dynamiek van het Deerlijkse dialect. Gent: KANTL.

Vandekerckhove, Reinhild. 2005. Belgian Dutch versus Netherlandic Dutch: New patterns of divergence? On pronouns of address and diminutives. Multilingua 24. 379-397.

Vandekerckhove, Reinhild, \& Judith Nobels. 2010. Code eclecticism: Linguistic variation and code alternation in the chat language of Flemish teenagers. Journal of Sociolinguistics 14. 657-677.

Vandenbussche, Wim. 2010. Standardisation through the media. The case of Dutch in Flanders. Variatio Delectat. Empirische Evidenzen und theoretische Passungen sprachlicher Variation, ed. by Peter Gilles, Joachim Scharloth, Evelyn Zieger, 309-322. Frankfurt am Main: Peter Lang.

Vlaams Parlement. 2012. Handelingen. Commissievergadering. Commissie voor Cultuur, Jeugd, Sport en Media van 29 november 2012.

http://www.vlaamsparlement.be/Proteus5/showVIVerslag.action?id=6840 56. Last accessed January 2013.

Willemyns, Roland. 1996. Pluricentric principles in the standardization of 19th century Dutch. Word-Journal of the International Linguistics Association, 47. 63-72.

Willemyns, Roland. 2007. De-standardization in the Dutch language territory 
at large. Standard, variation and language change in Germanic languages, ed. by Christian Fandrych \& Reinier Salverda, 265-279, Tübingen: Gunter Narr Verlag.

Willemyns, Roland. 2013. Dutch. Biography of a language. Oxford: Oxford University Press.

Willemyns, Ronald, \& Wim Daniëls (eds.). 2003. Het verhaal van het Vlaams. Antwerpen: Standaard.

Woolard, Kathryn. 1998. Simultaneity and bivalency as strategies in bilingualism. Journal of Linguistic Anthropology 8. 3-29. 